\title{
THE RELATIONSHIP AMONG LEARNING INDEPENDENCE, LEARNING DISCIPLINE AND NUMERICAL ABILITY WITH MATHEMATICS LEARNING OUTCOMES OF STUDENTS GRADE VII SMP MUHAMMADIYAH 9 YOGYAKARTA
}

\author{
Nadine Deninta Dido ${ }^{a}$, Nur Arina Hidayati ${ }^{b}$ \\ Mathematics Education Study Program Universitas Ahmad Dahlan \\ Jl. Ringroad Selatan, Tamanan, Bantul, Yogyakarta, \\ anadinedido29@gmail.com, b ${ }^{\text {nur.hidayati@pmat.uad.ac.id }}$
}

\begin{abstract}
The low of mathematics learning outcome is influenced by many factors. Learning independence, learning discipline and numerical ability are some of the factors that may affect the mathematics learning outcomes of students. Therefore, this research was conducted in order to determine whether there is a positive and significant relationship between learning independence, learning discipline and numerical ability with mathematics learning outcomes of students grade VII SMP Muhammadiyah 9 Yogyakarta in even semester of the academic year 2015/2016. The population in this research was all students of class VII SMP Muhammadiyah 9 Yogyakarta in the academic year 2015/2016 consisting of 5 classes with a total of 183 students. Random sampling techniques used to get class samples and collected VII C as a sample that consists of 37 students. Techniques of data collection were conducted by questionnaire to learning independence and learning discipline, being a test method for numerical ability and mathematics learning outcomes. Test instruments used validity and reliability. Prerequisite test analysis using homogeneity, normality test, independent, and linearity test. Hypothesis testing data analysis using simple linear regression analysis and multiple regression analysis and correlation. The results showed that there is a positive and significant correlation among learning independence, learning discipline and numerical ability with mathematics learning outcomes with $\mathrm{F}$ count $=12.1486271>\mathrm{F}$ table $=3.27$ multiple correlation coefficient $(\mathrm{R})$ is 0.497054456 and the coefficient determination $\left(\mathrm{R}^{2}\right)$ is 0.5248098361 . While multiple regression equation $\hat{Y}=91.67974362+$ $0.2721162468 \mathrm{X}_{1}+0.4013598791 \mathrm{X}_{2}+0.4720896167 \mathrm{X}_{3}$, relatively contribution $\left(\mathrm{X}_{1}\right)=25.78224833 \%$, the relative contribution $\left(X_{2}\right)=36.63257052 \%$, the relative contribution $\left(X_{3}\right)=37.58518115 \%$ and effective contribution $\left(X_{1}\right)=13.53077742 \%$, the effective contribution $\left(X_{2}\right)=19.22513318 \%$ and the effective contribution $\left(\mathrm{X}_{3}\right)=19.72507261 \%$.
\end{abstract}

Keywords: Learning independence, learning discipline, numerical ability, mathematics learning outcomes.

\section{INTRODUCTION}

Mathematics is one branch of science that plays an important role in advancing the science of education and technology, this is because in every science there are mathematical aspects in it. The importance of learning mathematics is also inseparable from the role of mathematics itself in various types of life dimensions. The magnitude of the role in life, mathematics subjects become compulsory subjects for elementary to upper secondary students. The teacher as one of the educational actors has an important role in teaching mathematics so that mathematics can be easily accepted by students.

According to Dwi Siswoyo, et al. (2007: 131) in the context of formal education, teachers as educators have a position as professionals at the level of basic education, secondary education and early childhood education. Therefore teachers as professional educators characterized by ownership of professional certificates play a full role in increasing the dignity and quality of national education. Learning mathematics is different from other lessons that can be learned only by memorizing. To understand mathematical concepts in depth you must first understand the basic concepts of mathematics. This is because the mathematical object is abstract and full of interrelated concepts. This characteristic requires students to be more careful, thorough and diligent so that success in learning mathematics can be achieved. 
One factor that comes from within students (internal) which plays a role in the learning process is learning independence. Independence of learning is an individual effort to carry out learning activities on their own initiative, without relying on the help of others, actively determining what is learned, and how to learn it with one's own ability to solve the problem. Students who have the desire to learn independently means that they have realized the importance of getting good learning outcomes. Another factor that students have is discipline. Discipline is the attitude of someone who shows obedience and obedience to rules that aim to develop themselves in order to behave in an orderly manner. Students who are able to develop discipline in themselves during mathematics learning will be able to achieve success in learning in order to obtain good learning outcomes. According to Samekto (1987: 7), the success of someone in learning mathematics is influenced by several factors, namely: interest, intelligence, willingness and ability to mathematics. These abilities are one of them is numerical ability. Numerical ability is the ability to calculate, reason with numbers related to ways of thinking that are fast, precise, careful, accurate and the ability to solve mathematical problems. Students who are able to develop their numerical abilities when performing calculations in mathematical problems play an important role in obtaining good mathematics learning outcomes.

Independence comes from the word "independent". In the Large Indonesian Dictionary, independent means that it can stand alone. While independence means showing the belief in the ability of oneself to solve problems without help from others. According to Nurhayati, Eti. (2011: 140) learning independence is learning on its own initiative, with or without the help of others to make important decisions in finding their learning needs. According to Holstein, Herman (1986: 186) independence is an important element in every learning and clearly can improve quality, because it involves the initiative of students. In the learning process each student is always directed to become independent students, and to be independent one must learning, so that learning independence can be achieved.

In the Large Indonesian Language Dictionary (KBBI), the word discipline has the meaning of order (in school, military, etc.) and obedience (obedience) to regulations (order, etc). According to Stara, Waji in his book Amri, Sofan (2013: 161-162) states that: Discipline comes from the Latin language discern which means learning. From this word, the word discipline arises which means teaching or training. And now, the word discipline experiences the development of meaning in several senses. First, the discipline is defined as compliance with regulations or subject to supervision and control. Both disciplines are exercises that aim to develop themselves in order to behave in an orderly manner.

Understanding the ability of numbers according to Sukardi, Dewa Ketut (1985: 166) is: The ability of numbers is one of the factors or elements of all abilities to master various tasks related to academic tasks. The subtest of numerical ability reveals to someone how they should understand ideas expressed in numbers, and how clear they are to be able to think and reason with numbers. According to Samekto (1987: 7) "The success of someone in learning mathematics is influenced by several factors, namely: interest, intelligence, willingness and ability to mathematics." These abilities include reasoning ability, spatial ability, verbal ability, and numerical abilities. Numerical ability is a mathematical ability that contains the ability to complete operations to calculate a number and mathematical symbols that are related to accuracy and accuracy in their calculations.

The problems in this study are: 1) Is there a positive and significant relationship between students' learning independence and the mathematics learning outcomes of seventh-graders in SMP Muhammadiyah 9 in the academic year 2015/2016? mathematics learning outcomes of seventh-grade students of SMP Muhammadiyah 9 Yogyakarta in the academic year 2015/2016? Is there a positive and significant relationship between student learning independence and student learning discipline with the mathematics learning outcomes of seventh-graders in SMP Muhammadiyah 9 in the academic year 2015/2016? study mathematics in grade VII semester students at SMP Muhammadiyah 9 Yogyakarta academic year 2015/2016? and significant between student learning independence, student learning discipline and numerical ability with the mathematics learning outcomes of class VII students of SMP Muhammadiyah 9 Yogyakarta in the academic year of 2015/2016?. 
The purpose of this study is: 1) To determine whether there is a positive and significant relationship between students' learning independence with the mathematics learning outcomes of seventh grade students of SMP Muhammadiyah 9 Yogyakarta in the academic year 2015/2016, 2) To determine whether there is a positive and significant relationship between student learning discipline with mathematics learning outcomes of seventh graders in SMP Muhammadiyah 9 in academic year of 2015/2016, 3) To determine whether there is a positive and significant relationship between numerical ability and mathematics learning outcomes of seventh grade students of SMP Muhammadiyah 9 Yogyakarta academic year 2015 / 2016, 4) To find out whether there is a positive and significant relationship between student learning independence and student learning discipline with the mathematics learning outcomes of seventh graders in SMP Muhammadiyah 9 in academic year of 2015/2016, 5) To determine whether there is a positive relationship and significant between disciplines student learning and numerical abilities with mathematics learning outcomes of seventh grade students of SMP Muhammadiyah 9 Yogyakarta 2015/2016 academic year, 6) To determine whether there is a positive and significant relationship between student learning independence and numerical ability with the mathematics learning outcomes of seventh semester students in grade VII SMP Muhammadiyah 9 Yogyakarta 2015/2016 academic year, 7) To find out whether there is a positive and significant relationship between student learning independence, student learning discipline and numerical ability with the mathematics learning outcomes of seventh graders in SMP Muhammadiyah 9 in the academic year of 2015/2016.

\section{METHODS}

This type of research uses a form of research design in the form of a Model of the Linkages between Three Free Variables and Bound Variables (Sugiyono, 2013: 69). In this study using one class, namely the sample class. The population in this study were all seventh-grade students of SMP Muhamamdiyah 9 Yogyakarta academic year 2015/2016 which amounted to 183 students. While the sample in this study is class VII C, the sampling technique used is a random sampling of the class. Data collection techniques used were questionnaire techniques with instruments in the form of questionnaires and test techniques in the form of objective questions of multiple-choice forms. Prerequisite test analysis with homogeneity test with Bartlet Test formula, normality test with Chi-squared formula, test independence of Chi-square formula and linearity test of F-test formula. The research hypothesis test uses a simple correlation test, multiple regression analysis and multiple linear regression tests with three independent variables. The research hypothesis test uses a simple correlation test to determine whether or not there is a positive and significant relationship between 1) learning independence with students' mathematics learning outcomes, 2) learning discipline with mathematics learning outcomes, 3) numerical abilities with mathematics learning outcomes. Furthermore, the research hypothesis test using a multiple regression analysis tests was conducted to determine whether or not there is a positive and significant relationship between 1) learning independence and discipline of learning with students' mathematics learning outcomes, 2) learning discipline and numerical abilities with student mathematics learning outcomes learning independence and numerical abilities with student mathematics learning outcomes. While the multiple linear regression test with three independent variables was conducted to determine whether there was a positive and significant relationship between learning independence, learning discipline, and numerical ability with students' mathematics learning outcomes. 


\section{RESULT}

\section{Prerequisite Test And Regression Analysis}

The summary results of the initial homogeneity test can be seen in Table 1 .

Table 1. Summary of Homogeneity Test Results

\begin{tabular}{|l|c|c|c|}
\hline Instrument & $\chi^{\mathbf{2} \text { count }}$ & $\boldsymbol{\chi}^{\mathbf{2}}$ table & Information \\
\hline $\begin{array}{l}\text { UTS Mathematics } \\
\text { Results class VII } \\
\text { A, VII B, VII C, } \\
\text { VII D and VII E }\end{array}$ & 8.7587 & 9.4877 & Homogen \\
\hline
\end{tabular}

From the normality test at a significant level of $5 \% \chi^{2}$ count $\leq \chi^{2}$ table this means that all class VII are homogeneous.

The summary of the results of the normality test can be seen in Table 2 .

Table 2. Summary of Normality Test Results

\begin{tabular}{|c|c|c|c|}
\hline Variable & $\boldsymbol{\chi}^{\mathbf{2}}$ count & df & $\boldsymbol{\chi}^{\mathbf{2}}$ table \\
\hline $\mathrm{X}_{1}$ & 2.4076 & 4 & 9.488 \\
\hline $\mathrm{X}_{2}$ & 6.4751 & 3 & 7.815 \\
\hline $\mathrm{X}_{3}$ & 8.4444 & 4 & 9.488 \\
\hline $\mathrm{Y}$ & 4.9264 & 2 & 5.991 \\
\hline
\end{tabular}

From the normality test at a significant level, $5 \%$ is seen $\chi^{2}$ count $\leq \chi^{2}$ table, this means that the distribution of data obtained in each variable is normally distributed.

The summary of linearity test results can be seen in Table 3 .

Table 3. Summary of Linearity Test Results

\begin{tabular}{|l|c|c|}
\hline Variable & $\mathbf{F}_{\text {count }}$ & $\mathbf{F}_{\text {table }}$ \\
\hline $\mathrm{X}_{1}$ and $\mathrm{Y}$ & 1.0865 & 2.44 \\
\hline $\mathrm{X}_{2}$ and $\mathrm{Y}$ & 1.3899 & 2.51 \\
\hline $\mathrm{X}_{3}$ and $\mathrm{Y}$ & 0.5691 & 2.43 \\
\hline
\end{tabular}

From the linearity test at a significant level of $5 \%(\alpha=0.05)$ and the degree of freedom $v_{1}$ numerator $\mathrm{k}-2$ and $v_{2}$ the denominator $\mathrm{n}-\mathrm{k}$ is visible $\left.\mathrm{F}_{\text {count }} \leq \mathrm{F}_{\text {table }}(1-\alpha)(\mathrm{k}-2, \mathrm{~N}-\mathrm{k})\right)$, this means that there is a linear relationship between the independent variable $(\mathrm{X})$ and the dependent variable $(\mathrm{Y})$.

The summary results of the initial capability normality test can be seen in Table 4 .

Table 4. Independent Test Result Summary

\begin{tabular}{|c|c|c|}
\hline Research Variable & $\boldsymbol{\chi}^{\mathbf{2}}$ count & $\boldsymbol{\chi}^{\mathbf{2}}$ table \\
\hline $\mathrm{X}_{1}$ and $\mathrm{X}_{2}$ & 14.356 & 37.652 \\
\hline $\mathrm{X}_{1}$ and $\mathrm{X}_{3}$ & 21.795 & 37.652 \\
\hline $\mathrm{X}_{2}$ and $\mathrm{X}_{3}$ & 30.049 & 37.652 \\
\hline
\end{tabular}

From independent tests at a significant level of $5 \%(\alpha=0.05)$ and degrees of freedom $(\mathrm{df})=\mathrm{k}-1)$ (b-1) seen $\chi^{2}$ count $\leq \chi^{2}$ table, this means that the distribution of data obtained on each variable is mutually independent.

\section{Hypothesis Testing}

The summary of the results of the first hypothesis test can be seen in Table 5 .

Table 5. Summary of First Hypothesis Test Results

\begin{tabular}{|c|c|c|c|}
\hline $\boldsymbol{t}_{\text {count }}$ & $\boldsymbol{t}_{\text {table }}$ & df & Information \\
\hline 3.1842 & 2.030 & 35 & $\begin{array}{l}\mathrm{H}_{0} \text { is rejected, } \\
\mathrm{H}_{1} \text { is accepted }\end{array}$ \\
\hline
\end{tabular}


From the first hypothesis test at a significant level of $5 \%$ and $\mathrm{df}=35$, it can be seen that $\boldsymbol{t}_{\text {count }}=$ 3.1842 and $\boldsymbol{t}_{\text {table }}=2.030$ so that $\boldsymbol{t}_{\text {count }}>\boldsymbol{t}_{\text {table }}$ which means that there is a positive and significant relationship between learning independence and the mathematics learning outcomes of seventh-graders in SMP Muhamamdiyah 9 Yogyakarta in the academic year 2015/2016.

The summary of the results of the second hypothesis test can be seen in Table 6 .

Table 6. Summary of Results of the Second Hypothesis Test

\begin{tabular}{|c|c|c|l|}
\hline $\boldsymbol{t}_{\text {count }}$ & $\boldsymbol{t}_{\text {table }}$ & Df & Information \\
\hline 3.9430 & 2.030 & 35 & $\begin{array}{l}\mathrm{H}_{0} \text { is rejected, } \\
\mathrm{H}_{1} \text { is accepted }\end{array}$ \\
\hline
\end{tabular}

From the second hypothesis test at a significant level of $5 \%$ and $\mathrm{df}=35$, it can be seen that $t_{\text {count }}=3.9430$ and $t_{\text {table }}=2.030$ so that $t_{\text {count }}>t_{\text {table }}$. This means that there is a positive and significant relationship between students' learning discipline with the mathematics learning outcomes of seventh-grade students in SMP Muhamamdiyah 9 Yogyakarta academic year 2015/2016.

The summary of the results of the third hypothesis test can be seen in Table 7.

Table 7. Summary of Third Hypothesis Test Results

\begin{tabular}{|c|c|c|l|}
\hline $\boldsymbol{t}_{\text {count }}$ & $\boldsymbol{t}_{\text {table }}$ & Df & Information \\
\hline 3.2416 & 2.030 & 35 & $\begin{array}{l}\mathrm{H}_{0} \text { is accepted, } \\
\mathrm{H}_{1} \text { is rejected }\end{array}$ \\
\hline
\end{tabular}

From the third hypothesis test at a significant level of $5 \%$ and $\mathrm{df}=35$, it can be seen that $\boldsymbol{t}_{\text {count }}=3.2416$ and $\boldsymbol{t}_{\text {table }}=2.030$ so that $\boldsymbol{t}_{\text {count }}<\boldsymbol{t}_{\text {table }}$ which means that there is no positive and significant relationship between numerical ability and the mathematics learning outcomes of seventhgraders in SMP Muhamamdiyah 9 in the 2015/2016 academic year.

The summary of the results of the fourth hypothesis test can be seen in Table 8 .

Table 8. Summary of Test Results for the Fourth Hypothesis

\begin{tabular}{|c|c|c|c|}
\hline $\boldsymbol{F}_{\text {count }}$ & $\boldsymbol{F}_{\text {table }}$ & Dk & Information \\
\hline 9.6127 & 3.25 & $v_{1}=2$ & $\mathrm{H}_{0}$ is rejected, \\
& & $v_{2}=35$ & $\mathrm{H}_{1}$ is accepted \\
\hline
\end{tabular}

From the fourth hypothesis test at a significant level of $5 \%, v_{1}$ numerator $=2$ and $v_{2}$ numerator= 35 so that it can be obtained $F_{\text {count }}=9.6127$ and $F_{\text {table }}=3.27$ a positive and significant relationship between student learning independence and student learning discipline with the mathematics learning outcomes of seventh-graders in SMP Muhamamdiyah 9 in the 2015/2016 academic year.

The summary of the results of the fifth hypothesis test can be seen in Table 9.

Table 9. Summary of Test Results for the Fifth Hypothesis

\begin{tabular}{|c|c|c|c|}
\hline $\boldsymbol{F}_{\text {count }}$ & $\boldsymbol{F}_{\text {table }}$ & Df & \multicolumn{1}{c|}{ Information } \\
\hline 9.9170 & 3.27 & $v_{1}=2$ & $\mathrm{H}_{0}$ is accepted, \\
& & $v_{2}=35$ & $\mathrm{H}_{1}$ is rejected \\
\hline
\end{tabular}

From the fifth hypothesis test at a significant level of 5\%, numerator $v_{1}=2$ and $v_{2}$ numerator $=$ 35 so that it can be obtained $F_{\text {count }}=3.27$ and $F_{\text {table }} \mathrm{e}=3.27$ so $F_{\text {count }} \leq F_{\text {table }}$ which means there is no positive and significant relationship between student learning discipline and numerical ability with the results of mathematics learning in seventh-grade students of SMP Muhamamdiyah 9 Yogyakarta in the 2015/2016 academic year.

The summary of the results of the sixth hypothesis test can be seen in Table 10 . 
Table 10. Summary of Results of the Sixth Hypothesis

\begin{tabular}{|c|c|c|c|}
\hline $\boldsymbol{F}_{\text {count }}$ & $\boldsymbol{F}_{\text {table }}$ & Df & Information \\
\hline 13.1449 & 3.27 & $\begin{array}{c}v_{1}=2 \\
v_{2}=35\end{array}$ & $\begin{array}{l}\mathrm{H}_{0} \text { is rejected, } \\
\mathrm{H}_{1} \text { is accepted }\end{array}$ \\
\hline
\end{tabular}

From the sixth hypothesis test at a significant level of 5\%, numerator $v_{1}=2$ and $v_{2}$ numerator $=35$ so that it can be obtained $F_{\text {count }}=13.1449$ and $F_{\text {table }}=3.27$ so $F_{\text {count }} \geq F_{\text {table }}$ which means there is a positive and significant relationship between student learning independence and numerical ability with results studied mathematics in seventh-grade students in SMP Muhamamdiyah 9 Yogyakarta in the 2015/2016 academic year.

The summary of the results of the seventh hypothesis test can be seen in Table 11.

Table 11. Summary of the Seventh Hypothesis Test Results

\begin{tabular}{|c|c|c|c|}
\hline $\boldsymbol{F}_{\text {count }}$ & $\boldsymbol{F}_{\text {table }}$ & Df & Information \\
\hline 12.1486 & 2.89 & $v_{1}=3$ & $\mathrm{H}_{0}$ is rejected, \\
& & $v_{2}=33$ & $\mathrm{H}_{1}$ is accepted \\
\hline
\end{tabular}

From the seventh hypothesis test at a significant level of $5 \%, v_{1}$ numerator $=3$ and $v_{2}$ numerator $=30$ so that it can be obtained $F_{\text {count }}=12.1486$ and $F_{\text {table }}=2.89$ so that $F_{\text {count }} \geq F_{\text {table }}$ which means that there is a positive and significant relationship between student learning independence, student learning discipline and numerical ability with the mathematics learning outcomes of seventhgraders in SMP Muhamamdiyah 9 Yogyakarta in the academic year 2015/2016.

\section{CONCLUSION}

Based on the analysis of the experimental data and the discussion, this activity concludes the following:

1. There is a positive and significant relationship between learning independence $\left(\mathrm{X}_{1}\right)$ with mathematics learning outcomes (Y) class VII grade students in the even semester of SMP Muhamamdiyah 9 Yogyakarta academic year 2015/2016. This is indicated by the t-test which is $t_{\text {count }}=3.1842>t_{\text {table }}=2.030$. The simple correlation coefficient $(r)$ between learning independence and mathematics learning outcomes is 0.4739 and also the coefficient of determination $\left(r^{2}\right)$ is 0.2246 . And the simple regression equation $\mathrm{Y}$ over $\mathrm{X}_{1}$ is $\hat{Y}=-10.8203+$ $0.6901 \mathrm{X}_{1}$.

2. There is a positive and significant relationship between learning discipline $\left(\mathrm{X}_{2}\right)$ with mathematics learning outcomes (Y) VII grade students in semester 9 of SMP Muhamamdiyah 9 in Yogyakarta academic year 2015/2016. This is indicated by the $t$-test which is $t_{\text {count }}=3.9430>t_{\text {table }}=2,030$. The simple correlation coefficient $(\mathrm{r})$ between disciplines of learning with mathematics learning outcomes of 0.5545 and also the coefficient of determination $\left(r^{2}\right)$ of 0.3075 . In addition, also obtained a simple regression equation $\mathrm{Y}$ over $\mathrm{X}_{2}$ is $\hat{Y}=-19.0547+0.8508 \mathrm{X}_{2}$.

3. There is a positive and significant relationship between numerical abilities $\left(\mathrm{X}_{3}\right)$ with mathematics learning outcomes (Y) VII grade students in SMP Muhamamdiyah 9 in Yogyakarta academic year $2015 / 2016$. This is indicated by the $t$-test which is $t_{\text {count }}=3.2416>t_{\text {table }}=2,030$. A simple correlation coefficient (r) between numerical abilities and mathematics learning outcomes is 0.4805 and also the coefficient of determination $\left(r^{2}\right)$ is 0.2309 . In addition, also obtained a simple regression equation $\mathrm{Y}$ on $\mathrm{X}_{3}$ is $\hat{Y}=-31.2932+0.8464 \mathrm{X}_{3}$.

4. There is a positive and significant relationship between learning independence $\left(\mathrm{X}_{1}\right)$ and learning discipline $\left(\mathrm{X}_{2}\right)$ with mathematics learning outcomes $(\mathrm{Y})$ VII grade students in semester 9 of SMP Muhamamdiyah 9 in Yogyakarta academic year 2015/2016. This is indicated by the F test which is $\mathrm{F}_{\text {count }}==9.6127 \geq \mathrm{F}_{\text {table }}=3.27$. The multiple correlation coefficient $(R)$ between learning independence and disciplinary learning with mathematics learning outcomes is 0.6010 and the coefficient of determination $\left(R^{2}\right)$ is 0.3612 with the linear line equation $\hat{Y}=-34.6454+$ 
$0.3870 \mathrm{X} 1+0.6507 \mathrm{X}_{1}$. The relative contribution of $\mathrm{X}_{1}$ is $34.87448 \%$ and $\mathrm{X}_{2}$ is $65.3155 \%$ and the effective contribution of $\mathrm{X}_{1}$ is $12.5969 \%$ and $\mathrm{X}_{2}$ is $23.5239 \%$.

5. There is a positive and significant relationship between learning discipline $\left(\mathrm{X}_{2}\right)$ and numerical ability $\left(\mathrm{X}_{3}\right)$ with mathematics learning outcomes (Y) VII grade students in SMP Muhamamdiyah 9 in Yogyakarta academic year 2015/2016. This is indicated by the $\mathrm{F}$ test, namely $\mathrm{F}_{\text {count }}=$ $9.9170 \geq \mathrm{F}_{\text {table }}=3.27$. The multiple correlation coefficient $(\mathrm{R})$ between learning independence and discipline of learning with mathematics learning outcomes is 0.6804 and the coefficient of determination $\left(R^{2}\right)$ is 0.4630 with the linear line equation $\hat{Y}=-73.4773+0.7494 \mathrm{X} 2+$ $0.7042 \mathrm{X} 2$. The relative contribution of $\mathrm{X}_{2}$ is $58.5112 \%$ and $\mathrm{X}_{3}$ is $41.4887 \%$ and the effective contribution of $X_{2}$ is $27.0932 \%$ and $X_{3}$ is $19.2111 \%$.

6. There is a positive and significant relationship between learning independence $\left(\mathrm{X}_{1}\right)$ and numerical ability $\left(\mathrm{X}_{3}\right)$ with mathematics learning outcomes (Y) VII grade students in SMP Muhamamdiyah 9 Yogyakarta academic year 2015/2016. This is indicated by the $\mathrm{F}$ test which is $\mathrm{F}_{\text {count }}=$ $13.1449 \geq \mathrm{F}_{\text {table }}=3.27$. Multiple correlation coefficient $(R)$ between learning independence and independence learning with mathematical learning outcomes of 0.6603 and coefficient of determination $\left(R^{2}\right)$ of 0.4360 with linear line equation $\hat{Y}=-79.6550+0.6601 \mathrm{X}_{2}+0.8108 \mathrm{X}_{3}$. Relative contribution of $\mathrm{X}_{1}$ is $49.2777 \%$ and $\mathrm{X}_{3}$ of $50.7222 \%$ and the effective contribution of $\mathrm{X}_{1}$ is $21.4879 \%$ and $\mathrm{X}_{3}$ is $22.1177 \%$.

7. There is a positive and significant relationship between learning independence, learning discipline and numerical ability with the mathematics learning outcomes of seventh-graders in SMP Muhamamdiyah 9 Yogyakarta in the 2015/2016 academic year. This is indicated by the F test which is $\mathrm{F}_{\text {count }}=12.1486 \geq \mathrm{F}_{\text {table }}=2.98$. The correlation coefficient $(\mathrm{R})$ between learning independence, discipline and numerical ability with mathematical learning outcomes of 0.7244 and determination coefficient $\left(R^{2}\right)$ of 0.5248 with linear line equation $\hat{Y}=-79.6550+0.6601 \mathrm{X}_{2}+$ $0.8108 \mathrm{X}_{3}$. The relative contribution of $\mathrm{X}_{1}$ is $25.7822 \%, \mathrm{X}_{2}$ is $36.6325 \%$ and $\mathrm{X}_{3}$ is $37.5851 \%$ and the effective contribution of $X_{1}$ is $13.5307 \%, X_{2}$ is $19.2251 \%$ and $X_{3}$ is $19.7250 \%$.

\section{REFERENCES}

Amri, Sofan. 2013. Pengembangan dan Model Pembelajaran dalam Kurikulum 2013. Jakarta: PT Prestasi Pustaka Publisher.

Nurhayati, Eti. 2011 .Psikologi Pendidikan Inovatif. Yogyakarta: Pustaka Pelajar.

Holstein, Herman. 1986. Murid Belajar Mandiri. Bandung: Remadja Karya.

Samekto.1987.Kemampuan Matematika Dalam Hubungannya Dengan Pengajaran Matematika. Makalah Seminar: IKIP Yogya.

Sugiyono.2013. Metode Penelitian Pendidikan (Pendekatan Kualitatif, Kuantitatif, $R \& D)$.Bandung:Alfabeta.

Sukardi, Dewa Ketut. 1985. Pengantar Teori Konseling. Jakarta: Balai Aksara-Yudhistira dan Pustaka Saadiyah. 